\title{
Pembaharuan Nahwu Menurut Shauqi Dhaif dan Ibrahim Musthafa
}

\author{
Fatkhur Roji \\ Sekolah Tinggi Agama Islam (STAI) Al-Aqidah Al-Hasyimiyyah Jakarta \\ fatkhurroji661@gmail.com
}

\begin{abstract}
Abstrak
Nahwu merupakan dasar dari ilmu bahasa Arab yang muncul pada abad pertama hijriyah. kemudian nahwu berkembang luas terbukti dengan banyaknya buku-buku kajian tentang nahwu yg membahas metode-metode di dalamnya, ditambah dengan munculnya kelompok-kelompok yang melakukan pendekatan tertentu sejak abad kedua hijriyah, munculkan kelompok Basroh, Kufah, Bagdad, Andalus dan kelompok Mesir hingga adab kelima hijriyah. Dalam Abad modern ini telah tampak upaya dari ahli bahasa Arab untuk merekonsktrusi bahasa Arab agar mudah dipahami oleh pelajar modern baik di Arab maupun non Arab. Penelitian ini termasuk jenis penelitian studi pustaka yang menggunakan pendekatan studi tokoh. Adapun yg menjadi sumber primer dalam penelitian ini adalah Kitab Ihyaun Nahwi karangan Ibrahim Musthofa dan Tajdidun Nahwi karangan Syauqi Dhoif. Data yang diperolah dianalisis dengan dua tahap, tahap pertama menggunakan analisis taksonomi dan kedua menggunakan analisis komparatif. Adapun hasil dari penelitian ini menunjukkan Ibrahim Musthofa mendasari upaya pembaruan nahwu dengan pendekatan makna dan ini serupa dengan pemikiran J.R Firth, Syauqi Dhoif mendasari upaya pembaruan nahwunya dengan pendekatan fonologi menunjukkan pengaruh dari pemikiran Bloomfield. Adapun aspek persamaan dalam konsep pembaruan adalah menolak adanya istilah alamat far'iyah dalam i'rob, mereka juga meniadakan bab كان dan saudaranya, ن كاد dan saudaranya dalam bab al-marfu'at, mereka juga menyepakati bahwa isim yang jatuh setelah ظن bukan merupakan tarkib isnadi. Aspek perbedaan keduanya dapat diringkas dari dasar landasan pembaruan dan dalam menyusun beberapa bab nahwu.
\end{abstract}

Kata Kunci: Pembaharuan, Nahwu, Shauqi Dhaif, Ibrahim Musthafa

\section{Abstract}

Nahwu is the basis of Arabic science that emerged in the first century hijrah. then nahwu widespread evidenced by the many books the study of nahwu that discuss the methods in it, coupled with the emergence of groups that perform particular approach since the second century hijrah, trigger group basroh, Kufa, Baghdad, andalus and groups of Egyptians until adab to five hijrah. In this modern century has seemed the efforts of Arabic linguists to reconstruct the Arabic language to be easily understood by modern scholars in both the Arab 
and non Arab. This research includes research literature that uses character study approach. As for who becomes the primary source in this study was the Book of Ibraham Musthofa النحو إحياءbouquet and النحو جديد Syauqi dhoif bouquet. The data obtained were analyzed in two stages, the first stage using taxonomic analysis and the second using comparative analysis. The results of this study indicate underlying Ibrahim Musthofa nahwu reform efforts with this approach is similar to the meaning and thought JR Firth, Syauqi dhoif underlying reform efforts nahwunya with phonological approach shows the influence of the thought of Bloomfield. As for the aspect of equality in the concept of renewal is وأخواهتا كان refused their term far'iyah address in i'rob, they also negate chapter , in chapter al-marfu 'at, they also agreed that isim that occur Aspects of the differences between them can be summarized from the foundation of the reform and in preparing several chapters nahwu.

\section{Keywords : Apdate, Nahwu, Shauqi Dhaif, Ibrahim Musthafa}

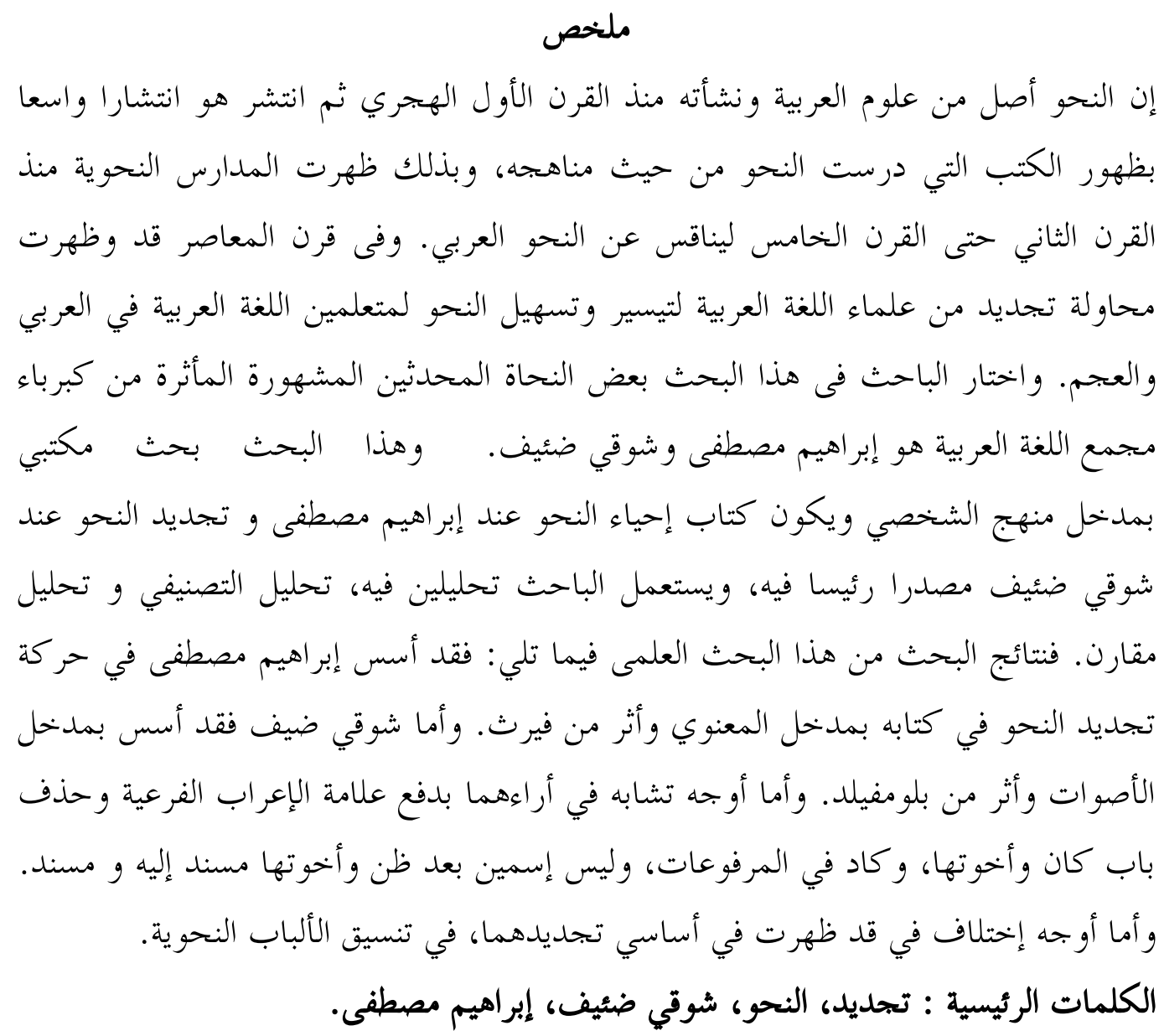




\section{Pendahuluan}

Upaya dalam memudahkan pengkajian ilmu nahwu telah ada sejak munculnya ilmu nahwu itu sendiri. Berbagai konsep dan metode telah dikemukakan oleh para tokoh nahwu, disadari atau tidak, bahwa perjalanan ilmu nahwu terus berjalan dari abad klasik dimana Ilmu Nahwu klasik yang telah menjadi satu disiplin ilmu di bawah tangan kreatif ulama Bashrah dan Kufah lalu disusul kemudian oleh ulama Baghdad dan Mesir, tidak terlepas dari kekurangan dan kritik konstruktif-epistemologis dari ulama Nahwu di belakangnya. Kritikan yang paling tajam sempat dilontarkan oleh seorang pakar bahasa Arab asal Kordova, Ibn Madla (w. 592 H) dalam ar-Radd 'ala Nuhat (Penolakan atas Ulama Nahwu) yang ditulis sekitar tahun $581 \mathrm{H}$. Penolakan Ibn Madla dalam kitab ini berkisar pada teori rasionalitas dalam pembentukan ilmu Nahwu klasik yang cenderung "dipaksakan", sehingga tak jarang kita menemukan kerumitan-kerumitan dalam memahami logika ilmu Nahwu. ${ }^{1}$

Hingga abad modern bahkan kontemporer saat ini. Tentunya terdapat banyak sejarah tokoh, pemikiran-pemikiran, serta perdebatan yang terjadi. yang telah banyak memberikan warna tersendiri dalam khazanah Ilmu Nahwu.Dengan landasan itu, kiranya perlu banyak kajian terhadap Ilmu nahwu dalam rangka menggali lebih dalam sejarah perkembangan nahwu hingga sekarang. Karena sesungguhnya hal itu akan menjadi bukti eksistensi suatu peradaban.

Dalam al-Muqaddimah-nya, Ibnu Khaldun memandang "Ilmu Nahwu” sebagai bagianintegral dari seluruh pilar linguistik Arab ('Ulum al-Lisany al Arab) yang terdiri empat cabang ilmu, yakni: Ilmu Bahasa ('Ilm al Lughah), Ilmu Nahwu ('Ilm al Nahwi), Ilmu Bayan ('Ilm al Bayan) dan Imu Sastra ('Ilm al Adab). ${ }^{2}$ Disiplin Nahwu ini pada masa formasinya sangat sederhana dan bersifat praktis, Didorong semangat rasa tanggung jawab terhadap agama, ilmu Nahwu dimaksudkan sebagai pelurusan terhadap bacaan-bacaan bahasa Arab (terutama ayatayat al-Qur'an) yang dianggap menyalahi bacaan konvensional. Kesalahan-kealahan bacaan tersebut dalam tradisi bahasa dan bangsa

${ }^{1}$ Arifudin, Akademi Ilmu Tata Bahasa Arab di Andalusia: Kronologi dan Kontribusi. (Surabaya, Jurnal Sastra Arab, 2013). Hal. 78.

${ }^{2}$ Al-Hasyimi, Al-Sayyid Ahmad, al-Qawaid al- Asasiyah Li al-Lughah alArabiyyah, (Jakarta: Dinamika Berkah Utama, 2012). Hal.98. 
Arab disebut "al-Lahn", yaitu kekeliruan dalam berbahasa yang karenanya telah dianggap tidak fasih lagi. ${ }^{3}$

Adalah Abu Aswad al-Dauli, seorang hakim di kota Bashrah, Irak, pada masa pemerintahan Ali bin Abi Thalib merasa prihatin terhadap semakin maraknya lahn. Abu Aswad yang juga sebagai ahli qira'at tentu merasa sangat bertanggung jawab untuk menjaga al-Qur'an dari pengaruh lahn. Oleh karena itu, dia mulai merumuskan tanda-tanda bacaan tertentu untuk mempertahankan bacaan yang mutawatir sanadnya. Dalam hal ini bacaan al-Qur'an yang ditulis pada masa khalifah Utsman bin Affan (al-Mushaf al-Utsmani).

Tanda-tanda bacaan yang dirumuskan oleh Abu Aswad ini sangat sederhana, yakni hanya berupa "titik-titik". Titik dibagian atas sebuah huruf, titik dibagian bawah huruf, dan titik dibagian kiri-atas sebuah huruf. ${ }^{4}$ Titik-titik pada huruf inilah yang kemudian hari dikenal dengan istilah "al-fathah, al-Kasrah dan al-Dhammah", kemudian pada periode perkembangan Nahwu, dalam arti yang sebenarnya, fathah, kasrah dan dhammah menjadi bagian yang terpenting dalam pembicaraan ilmu Nahwu tersebut, yaitu dijadikan sebagai tanda-tanda i'rab ('alamat alI'rab).

Ilmu Nahwu sebagaimana yang kita kenal sekarang ini yang sarat dengan berbagai aturan dan teori meupakan hasil dari sebuah proses yang cukup panjang dalam sejarah linguistik Arab. Dimulai dengan kegiatan kodifikasi dan sistemisasi kosakata bahasa Arab yang cukup menyita waktu, barulah para ahli bahasa (al-Lughawiyyun, linguistik) membangun dan meletakkan prinsip-prinsip dasar aturan bahasa tersebut. ${ }^{5}$ Prinsip-prinsip dasar nahwu pada mulanya bersifat sangat sederhana, kemudian berkembang menjadi sebuah "ilmu" yang sangat pelik dan rumit. Nahwu tidak lagi sekedar berfungsi sebagai aturan atau tatabahasa yang bersifat deduktif, tetapi juga telah menjadi (salah satu) instrumen memahami al-Qur'an itu sendiri yang pada gilirannya memunculkan banyak teori nahwu yang dikembangkan oleh para ahli

${ }^{3}$ Haniah, Analisis Kesalahan dalam Berbahasa Arab pada skripsi mahasiswa Jurusan Bahasa Arab dan Sastra Arab, (Makassar: Arobi:Journal Of Arabic Studies Vol. 3 No. 1, 2018).Hal. 34.

${ }^{4}$ Sri Guno Najiib Chaqoqo, Sejarah Nahwu, (Salatiga: LP2M Press IAIN Salatiga Cet. 1, 2015). Hal. 41.

5 Zam Zam Afandi, Bias Tiologis dalam Linguistik Arab, (Yogyakarta, Jurnal Adabiyat Vol. 7 No. 5, 2015). Hal. 145. 
nahwu. Hal ini tentu, paling tidak menurut hemat penulis, justru semakin mempersulit memahami dan mempelajari ilmu Nahwu itu sendiri. Teori-teori nahwu ini kian tambah rumit setelah ilmu ini juga dikembangkan oleh para teolog dan juga para filosof yang berupaya memasukkan prinsip-prinsip logika dan rasionalitas ke dalam ilmu nahwu. ${ }^{6}$ Kesan rumit dan pelik ini diperparah lagi dengan munculnya aliran-aliran dalam nahwu; aliran Basharh, Kufah, Bagdad dan Andalusia yang masing-masing memiliki karakter dan mengembangkan prinsip-prinsipnya sendiri.

Dengan rumitnya masalah nahwu, sehingga penulis perlu merumuskan bahwa pembaharuan nahwu menurut Shauqi Dhaif dan Ibrahim Musthafa, sehingga ditemukan perbedaan-perbedaan pembaharuan nahwu oleh kedua tokoh tersebut.

\section{Metode Penelitian}

Artikel ini merupakan studi literatur atau pustaka dengan pendekatan kualitatif. Penelitian kepustakaan adalah serangkaian kegiatan yang berkenaan dengan metode pengumpulan data pustaka, membaca dan mencatat serta mengolah bahan penelitian. Sumber primer penelitian ini adalah karya-karya Shauqi Dhaif dan Ibrahim Musthafa. Adapun metode yang digunakan adalah deskriptis analisis. Disebut deskriftis guna membuat gambaran secara sistematis, faktual dan akurat mengenai fakta-fakta, corak serta hubungan ${ }^{7}$ pembaruan nahwu yang diusung oleh keduanya. Adapun metode analisis ditujukan untuk menyelidiki secara terperinci terkait pembaharuan nahwu dari keduanya sehingga hasil penelitian ini dapat memberikan rekomendasirekomendasi untuk keperluan masa yang akan datang. ${ }^{8}$ Metode komparatif tidak luput digunakan dalam penulisan artikel ini untuk mendapatkan gambaran yang detail tentang perbedaan dan kesamaan Shauqi Dhaif dan Ibrahim Musthafa dalam pembaharuan nahwu.

\section{Biografi Shauqi Dhaif}

6 Toni Franciska, Konsep I'rob dalam Ilmu Nahwu "sebuah kajian epistemologis", (Yogyakarta: Jurnal al-Mahara Vol. 1, No. 1, 2015). Hal. 81.

${ }^{7}$ M. Nazir, Metode Penelitian. (Jakarta: Ghalia Indonesia, 1988). Hal. 63.

${ }^{8}$ Sugiyono, Memahami Penelitian Kualitatif. (Bandung: CV. Alfabeta, 2005). Hal. 11. 
yauqi Dhaif lahir di Aulad Hamam, Mesir pada 13 Januari 1910, dan wafat pada14 Maret 2005, pada usia 95 tahun.'Syauqi Dhaif mengawali upayanya dalam pembaharuan nahwu dengan pen-tahqiqannya terhadap buku karangan Ibnu Madha yaitu ar-Radd ala an-Nuhat wa al-Masyriq fi an-Nahwi, yang telah memberi warna baru dalam khazanah ilmu nahwu. Beliau merekonstruksi kembali pemikiran nahwu yang telah berkembang selama ini yang dianggap menyulitkan pengajaran nahwu dengan perinsip mudah, gampang, ringkas, sederhana, dan mudah dipahami oleh para pelajar bahasa Arab.

Beliau menuangkan pemikirannya tersebut dalam beberapa bukunya yaitu Tajdid al-Nahwi, Taisiraat Lughawiyah, dan Taisiru al-Nahwi al-Ta'limi Qadiman wa Haditsan ma'a Nahji Tajdidihi. Diantara ketiga buku ini, yang paling masyhur dalam khazanah ilmu nahwu adalah yang pertama yaitu Tajdid al-Nahwi, yang menyajikan konsep-konsep yang sempurna dalam pengajaran nahwu, dan juga memberi warna-warna baru yang disandarkan atas perinsip-perinsip dasar yang bersumber dari buku Ibnu Madha

Pada dasarnya karya-karya yang disusun beliau dimaksudkan untuk senantiasa dalam mempelajari nahwu menjadi lebih sederhana dan mudah dipahami, hal ini dimaksudkan supaya pembelajaran nahwu tidak mendapatkan kesulitan dalam memahami bab-bab nahwu.

\section{Biografi Ibrahim Musthafa}

Jika kita membahas tentang Ibrahim Mustafa tidak enak rasanya jika kita tidak mengetahui tentang beliau, beliau dilahirkan di andalus pada tahun 1863 hijriah dan meninggal pada tahun 1927 hijriah, ${ }^{10}$ Ibrahim musthafa adalah representasi kritikus dan pembaharu nahwu abad modern yang banyak mengilhami para ahli nahwu lain mengikuti pandangan dan pola berpikirnya. Ibrahim adalah seorang dosen pada fakultas Adab Universitas Fu'ad al-Awal (kini menjadi Universitas Kairo).

Pada tahun 1936 ia menyelesaikan karyanya dibidang nahwu yang ia beri judul "Ihya al-Nahwi" (revitalisasi ilmu nahwu) dan setahun

${ }^{9}$ Eva Ardinal, Pemikiran Syauqi Dhaif Dan Upaya Pembaharuannya di Bidang Pengajaran Nahwu, (Kerinci: Jurnal Islamika Vol. 13 No. 2, 2013). Hal. 178.

${ }^{10}$ Rena Umamawati,Min Naqd Ibrahim Musthafa Fi Ba'd Al Masaail Al Nahwiyah Fi Kitabihi Ihya Al Nahwi, (Surabaya: Tesis Universitas Islam Negeri Sunan Ampel, 2016). Hal. 37. 
kemudian yaitu pada bulan Juli 1937 diterbitkan oleh lajnat al-ta'lif wa al-tarjamah wa al-nasyr Kairo dengan kata pengantar doktor Taha Husain yang memuji buku tersebut, kitab ini menjadi salah satu dari kitab pertama tentang pembaharuan ilmu nahwu, dia memberi nama kitab ini berdasarkan saran dari doktor Taha Husain.

Pada bagian pengantarnya, Ibrahim Musthafa menyatakan sebagai berikut: "Buku ini membahas tentang nahwu yang aku geluti selama tuju tahun tetapi aku sajikan hanya dalam beberapa lembar saja. Tujuanku adalah untuk mengubah metode nahwu dalam mempelajari bahasa Arab, melenyapkan bahasan nahwu yang memberatkan para pelajar dan menggantinya dengan cara-cara yang mudah dan simpel sehingga mereka dapat dengan mudah mempelajari bahasa Arab, juga mengantarkan mereka dapat memahami uslub-uslubnya (stylistikanya)...". ${ }^{11}$

Dan pada akhir kitabnya dia beliau menyatakan "i'rab itu tidak ada pada fiil, i'rab itu hanya ada pada ism, karena fi'il itu tidak bisa dii'rab.

\section{Pembaharuan Nahwu Shauqi Dhaif}

Dalam pen-tahqiq-annya beliau merumuskan bahwa dalam upaya pembaharuan nahwu terdapat enam pokok konsep yang ditawarkan, yang meliputi:

a) Penyusunan kembali bab-bab dalam nahwu yang tumpang tindih, menambahkan, dan mengumpulkan bab-bab yang dianggap sejenis. Seperti contoh Bab كان واخوتها hendaknya dimasukkan pada bab fi'il lazim. Teori merofa'kan isim dan menasobkan khobar diubah dengan isimnya menjadi failnya dan khobarnya menjadi hal saja.

b) Menghapus dua peng-i'rab-an, yaitu taqdiri dan mahalli. Seperti contoh dari I;rab taqdiri adalah جاء الفتىdibaca rofa' tanpa harus menyebutkan rofa' muqoddar yang aslinya dzommah

c) Menghapus i'rab yang tidak efisien untuk kebenaran dalam pengucapan[4]. I'rab yang danggap tidak efisien tersebut adalah bab ististna', babadawat syarat, kam istifhamiyah dan khabariyah, kata لاسيمانlyang disukun.

d) Meletakkan pengertian-pengertian dan kaidah-kaidah yang lebih spesifik pada sebagian bab-bab nahwu. Secara garis besar Syauqi

${ }^{11}$ A.S. Ade Wahyu, Perkembangan Ilmu Nahwu Kontemporer, (Jakarta: Makalah UIN Syarif Hidayatullah, 2011). Hal. 1. 
Dzaif berpendapat ada tiga definisi topik pembahsan materi nahwu yang perlu diperbaharui, yaitu bab Maf'ul Mutlaq, Maf'ul $m a^{\prime} a h$, dan bab hal.

e) Membuang penambahan-penambahan dalam bab nahwu yang tidak penting. Seperti pembuangan kaidah-kaidah isim alat, karena isim alat bersandar pada sima'i, dan tidak membuthkan kaidah.

f) Penambahan topik yang dianggap signifikan. Seperti penambahan pembahasan khusus yang disertai kaidah-kaidah pengucapan atau makhraj, kerena dapat menumbuhkan kesadaran dalam menjaga al-Qur'an.

g) Beliau berpendapat bahwa fi'il mudhori' yang bersambung dengan nun taukid tidak berbeda dengan fi'il mudhori' yang di dahului oleh amil nashob dimana keduanya sama-sama berkhir dengan harakat fathah. Seperti pada contoh kalimat is أسافرَنَ dari. Sebagaimana telah diketahui bahwa fi'il mudhori'yang bersambung dengan nun taukid mabni fathah. ${ }^{12}$

Jika fi'il mudhori' yang bersambung dengan nun taukid لا تمدحَنَّ : لا لتمدحَنَّ Lafinashobkan sedang lafadz tersebut didahukui

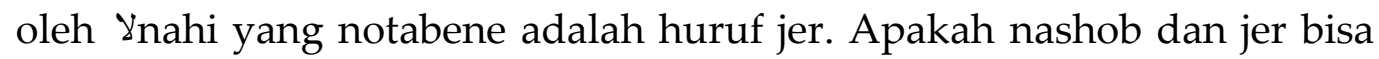
berkumpul dalam satu keadaan yang sama?

Beliau juga merekomendasikan untuk menyamakan fi'il mudhori' yang bersambung dengan nun niswah dalam I'rab jazem, Seperti pada contoh:

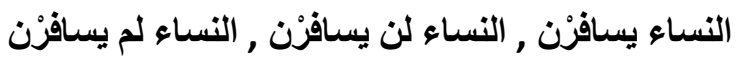

1. Beliau juga menganggap bahwa khobar dapat berupa marfu', mansub dan majzum.

a) Ketika nashob seperti contoh: ضربي العبدَ مسيئًاً

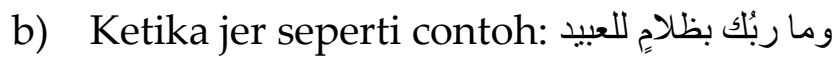

2. Anggapan beliau pada isim إن dan saudara-saudaranya sebagai mubtada' yang didaca nashob dengan hujjah bahwa mubtada' bisa dibaca jer ketika didahului oleh بُّلُan huruf jer yang

${ }^{12}$ Musthafa Ghalayaini, Jami'ud Durus al 'Arabiyyah, (Kairo: Darul Hadits, 2011). Hal. 76. 
berupa tambahan. Beliau berdalih: 'jika mubtada' bisa dibaca jer, kenapa kita tidak mengatakan kalau mubtada' bisa dibaca nashob?

a) Pada contoh: رُبَّ قولٍ أنفد من صولdan وليلٍ كموج البحر أرخى سدوله.

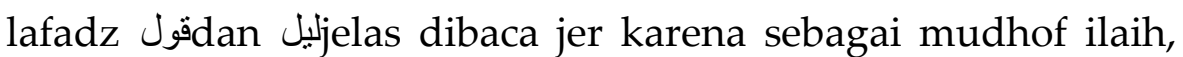
tetapi lafadz tersebut berkedudukan sebagai mubtada'. Sedang yang dimaksud oleh Dr. Syauqi Dhoif sebagai mubtada' yang dibaca nashob seperti pada contoh: إن اللةَ عليم خبير

3. Beliau mengatakan "sesungguhnya mudhaf ilaih itu menyerupai isim yang ikut pada isim yang lain walaupun wajib dibaca jer. Seperti contoh ثلاثة أقلام.disini jelas bahwa lafadz أقلام-mengikuti lafadz ثلاثة Bisa juga kta katakan الأقلام الثلاثث atau badal.

4. Beliau merekomendasikan untuk mengabaikan fa'il ataupun naibul fa'il ketika dalam bentuk dhomir mustatir. seperti contoh: زيد قام , محمد سُّنل Menurut hemat beliau, tidak perlu repotrepot mengi'rabi kedua contoh yang telah disebut karena fa'il dan naibul fa'il dari keduanya "hanya" dhomir yang tidak terlihat oleh mata.

5. Rekomendasi beliau untuk mengabaikan I'rab pada jumlah. Pada contoh: مررت برجل يزرعlafadz يزرعdii'rabi jer karena sebagai sifat

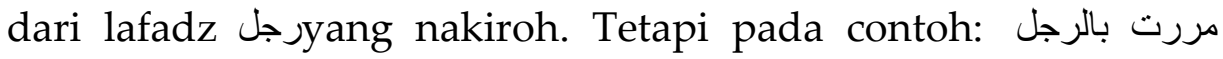
يزر إع lafadam keadaan nashob karena sebagai hal. Sebagaimana perkataan para ahli nahwu bahwa "setiap jumlah yang jatuh setelah isim nakiroh berupa sifat, tetapi jika setelah ma'rifat maka jumlah tersebut berkedudukan sebagai hal.

6. Beliau menganjurkan untuk mendalami penjelasan tentang kedudukan isim mabni, isim manqus, dan isim maqsur. Beliau berpendapat bahwa isim-isim ini perlu pejelasan lebih detail tentang kedudukannya pada kalimat, yang mana pada setiap I'rab yang ditempati, isim-isim ini tetap sama seperti sediakala. ${ }^{13}$

\section{Pembaharuan Nahwu Ibrahim Musthafa}

1. Redevenisi Nahwu

${ }^{13}$ Ali Muzhir Al Yasiri, Al-Fikr al-Nahw 'inda al 'Arb Usulu wa Manahijuhu, (Beirut: al Dar al-Arabiyyah Li al Maushu' at, 2012). Hal. 89. 
Sebelum mengajukan definisi nahwu menurut versinya, Ibrahim Musthafa terlebih dahulu mengkritik para ulama'nahwu klasik yang pada umumnya memberi definisi nahwu dengan:"pengetahuan yang dengannya dapat diketahui posisi akhir kata baik dari segi mu'rab maupun mabninya"

Dengan definisi nahwu seperti itu, lanjut Ibrahim, kajian nahwu hanya berkutat dan terfokus pada pada huruf-huruf terakhir pada sebuah kata-kata, khususnya lagi tentang mu'rab dan mabninya. Definisi seperti ini, kritik Ibrahim, sama dengan mempersempit wilayah kajian nahwu.

Bagi Ibrahim pengertian nahwu adalah "aturan penyusunan kalimat dan penjelasan posisi setiap kata yang ada di dalamnya, posisi kalimat dalam kaitannya dengan kalimat lain yang lebih luas, sehingga menjadi sebuah ungkapan/susunan yang sistematis dan memiliki pengertian yang memadai". ${ }^{14}$

2. Penolakan pada amil

Sebelum mengkritik dan menolak konsep amil ini, Ibrahim Musthafa terlebh dahulu menggali dan mengambil intisari dari konsep amil tersebut dengan menyatakan sebagai berikut: "lebih dari seratus ribu tahun mereka menekuni dan mengkaji masalah i'rab dan kaidah-kaidahnya, tetapi apa hasil yang mereka dapat dan kaidah-kaidahnya, tetapi apa hasil yang mereka dapat untuk membongkar rahasia i'rab dan hakikatnya? Pada prinsipnya kajian mereka menyatakan bahwa I'rab adalah wujud adanya pengaruh dari amil baik yang verbal (terucapkan) maupun yang tidak. Mereka membicarakan tentang amil, syarat-syaratnya dan cara kerjanya seacara panjang lebar hingga seolah-olah konsep amil bagi mereka adalah nahwu itu sendiri".

Beliau mengklarifikasikan sebagai berikut: ${ }^{15}$

a. Setiap tanda i'rab merupakan pengaruh dari amil, jika amil tersebut tidak disebutkan secara langsung maka harus diperkirakan (muqaddar), memang ada amil yang harus tidak disebutkan tetapi yang pasti ia wajib ditakdirkan

${ }^{14}$ Abdullah, ad-Dars an-Nahwi fi al- qarn al-isyrin, (Kairo: Maktabah Adab, 2004). Hal. 167.

${ }^{15}$ Hazuar, Konsep I'rab dalam Pandangan Ibrahim Mustafa dan Ibrahim Anis, (Curup : Jurnal Arabiyatuna Vol. 3 No. 1, 2019). Hal. 169. 
(muqaddar). Dalam satu jumlah bisa terdapat dua amil muqaddar yang tidak sama seperti dalam contoh:

$$
\text { "إستق اللهم سقيا دعائى للكسسقيا للك، تقديره" }
$$

b. Dua amil tidak boleh ada dalam waktu bersamaan untuk sebuah ma'mul. Kalau kasus ini terjadi maka para ulama' nahwu klasik membagi cara kerja keduanya, satu amil mempengaruhi terhadap lafadz sedangkan amil satunya lagi beroperasi pada segi posisinya seperti dalam kasusu kalimat:"بحسبك هذا". Huruf "ba" pada kata "hasbika" bermal pada lafadz "hasbika" itu sendiri, sedangkan amil ibtida'nya beramal pada posisinya yang menjadi mubtada'. Dari kasusu semacam ini lalu mereka menciptakan teori "al-Tanâzu'" (saling betrebut dalam beramal) yang sangat rumit dan berbelit-belit.

c. Pada prinsipnya yang dapat menjadi amil adalah fi'il semata dan hanya beramal pada isim, baik rafa' nashab. Fi'il hanyaa dapat merafa'kan satu isim saja, menasabkan lebih dari satu isim tetapi dapat merafa'kan dan menasabkan sekaligus.

d. Fi'il yang mutasharrif (bukan jamid) memiliki daya beramal sempurna, sedangkan fi'il jamid dapat berlaku sebagai amil tapi sebagai amil yang lemah. Ia tidak dapat beramal kepada kata yang mendahuluinya, bahkan diantaranya ada dapat menjadi amil setelah memenuhi beberapa syarat tertentu seperti fi'il yang berfungsi sebagai ta'ajub, juga kata ni'ma dan bi'sa. Sedangkan fi'il naqis hanya dapat beramal kepada mubtada' dan khabar.

e. Isim juga dapat berfungsi sebagai amil karena dipersamakan dulu dengan fi'il seperti isim fa'il, isim maf'ul dan isim mashdar. Setiap isim yang tidak memiliki kemiripan dengan fi'il maka ia tidak dapat beramal atau menjadi amil. Cara kerja isim tidak terbatas pada sesama isim saja, tetapi juga dapat beramal pada fi'il, ia dapat merafa'kan dan menashabkan isim, tetapi terhadap fi'il ia hanya dapat menjazamkan saja.

f. Huruf memiliki dua cara ia sebagai amil; pertama, ia berdiri sebagai huruf asli dan tidak dipersamakan terlebih dahulu 
dengan fi'il, kedua dapat beramal jarena dipersamakan dengan fi'il. Huruf dapat beramal baik terhadap isim maupun fi'il, ia merafa'kan, menasabkan dan mengejerkannya. Terhadap isim, huruf dapat beramal menjazamkan dan menasabkan. Jika huruf tersebut dalam proses amalnya dipersamakan dengan fi'il, maka kekuatan amalnya dilihat dari sejauhmana huruf tersebut memiliki kemiripan dengan fi'il baik dari segi makna maupun lafadznya. Huruf "inna", misalnya, ia dapat beramal karena ia memiliki arti yang berfungsi meperkuat pernyataan (taukid). Oleh sebab itu, ia memiliki kesamaan dengan fi'il dari segi maknanya, disamping itu huruf "inna" juga terdiri dari tiga huruf, karenanya ia mirip dengan fi'il dari segi bentuknya. Jika "syiddah" yang ada pada huruf "inna" itu dihilangkan dan menjadi "in" saja, maka ia akan kehilangan daya kemiripannya dengan fi'il yang berarti pula semakin lemah beramalnya.

g. Huruf baru bisa beramal setelah ia menjadi pasangan khusus bagi kata-kata atau kalimat tertentu. Huruf "lan" dan "lam" misalnya, keduanya dapat beramal terhadap fi'il mudhari' sebab keduanya memang hanya dapat berpasangan dengan fi'il mudhari'. Ini berbeda misalnya dengan huruf "qad", huruf ini tidak dapat beramal seba ia tidak memiliki pasangan khusus, ia dapat masuk pada fi'il mudhari' maupun fi'il madhi.

h. Sebuah huruf dapat beramal yang tidak sama dalam menurut konteks dan posisinya, misalnya seperti hurur "lâ", ia terkadang dapat beramal sebagaimana amalnya "laisa" dan juga beramal seperti huruf "inna".

i. Posisi amil berada sebelum ma'mulnya, tetapi jika amil itu termasuk kategori amil yang kuat, maka ia dapat diletakkan setelah ma'mulnya.

j. Pada prinsipnya antara amil dan ma'mul harus terkait langsung, tidak ada pemisah diantara keduanya, namun jika amil termasuk kategori yang kuat maka ia dapat dipisah dengan ma'mulnya. 
k. Amil-amil yang bekerja untuk fi'il memiliki posisi lebih lemah daripada amil-amil yang bekerja untuk isim. Sebab amil-amil yang bekerja untuk fi'il terkadang dapat dihilangkan jika telah terpenuhi syarat-syaratnya seperti huruf-huruf yang berfungsi sebagai“adawât al-syarthi".

1. Sebuah kata, dapat berfungsi sebagai amil dan juga ma'mul sekaligus, tetapi dua kata tidak dapat saling beramal.

m. Bagian kata saja tidak dapat berperana sebagai amil.

n. Ada beberapa amil yang hanya dapat beramal dari segi "mahalnya" saja, bukan pada lafadznya karena adanya halhal tertentu yang membuatnya demikian.

o. Sekelompok huruf yang memiliki cara beramal sama, maka mereka akan dimasukan dalam sebuah keluarga seperti "inna" dan "kâna". Masing-masing dari keluarga huruf tersebut memiliki cara kerja yang lebih luas. Itu sebabnya, ia disebut sebagai "ummul bab" (induk dari bab), masingmasing mereka juga memiliki hak beramal yang tidak dimiliki yang lain di luar kelompok mereka.

3. Penyatuan tempat antara mubtada, fail dan naibul fail

Menurut beliau disatukannya ketiga bab tersebut karena antara ketiganya itu sama-sama isim, karena ketiga hukumnya sama-sama rafa', kata beliau "jika kita melihat bab ini, kita akan menemukan bab yang menyebabkan ketiganya itu bisa dimasukkan dalam satu bab".

4. Fathah bukanlah alamat I'rob

Jika selama ini tanda I'rab yang dikenalkan dalam nahwu ada tiga macam yaitu; fathah, kasrah dan dhammah, maka menurut Ibrahim musthafa fathah tidak dimasukkan ke dalam salah satu tanda i'rab. Jadi menurutnya, tanda i'rab itu hanya ada dua yaitu dhammah dan kasrah, keduanya muncul bukan karena adanya pengaruh dari amil tetapi dari sipembicara sendiri untuk menentukan makna dari kalimat.

Dhlommah adalah tanda dari isnad, sedangkan kasroh adalah tanda dari idlafah, Dalam kategori yang dibuat Ibrahim ada dua bahasan nahwu yang termasuk menerima tanda kasrah ini atau yang disebut idafah yaitu idafah konvensional (kata majmuk) dan idafah yang didahului oleh huruf (jar) seperti huruf "min. ila' 'an. 'ala' fi' 
dan lain sebagainya yang olehnya disebut sebagai huruf idhafah (hurûf al-Idhafah).

Sedangkan fathah menurut beliau bukanlah termasuk dalam tanda I'rab karena menurut beliau fathah tidak enimbulkan atau menunjukkan ma'na apapun, adi sebenarnya fathah itu adalah tanda yang disukai orang arab dikarenakan fathah itu lebih ringan dari tanda yang lainnya.

5. Penolakan terhadap alamat I'rab fariyah (cabang)

Disamping i'rab asli (dhammah, kasrah dan fathah), para ahli nahwu klasik pada umumnya juga menciptakan i'rab cabang atau yang biasa disebut dengan "al-'Alâmat al-Far'iyyah" yang beperan sebabagi pengganti dari i'rab yang asli.

Dalam kasus al-Asma' al-Khamsah, seperti contoh-contoh berikut ini: "جاء أبوك، رأيت أباك، مررت بأبيك", menurut ahli nahwu klasik yang pertama alamat rafa'nya ditandai dengan huruf "wawu", yang kedua alamat nasabnya ditandai dengan huruf "alif" sedang dalam contoh ketiga alamat jarnya ditandai dengan huruf "ya'"

\section{Persamaan Menurut Shauqi Dhaif Dan Ibrahim Musthafa}

\section{Segi Sejarah}

Keduanya sama-sama terdapat pengaruh dalam pembaharuan nahwu sesuai yang tertuang dalam kitab al-Raddu 'ala al-Nuhah dan sesuai dengan penolakan Ibnu Madha dari Teori 'Amil yang penggunaannya sesuai pendapat ulama terdahulu dalam mabni nahwu araby.

\section{Segi Panjangnya}

Keduanya dalam sepanjang pembaharuan dan mempermudah dari pengembangan nahwu arab dalam kurun waktu 20 tahun, dan keduanya terdapat pembaharuan dalam bahasa Arab sesuai yang terlihat jelas pada karangan kitab keduanya.

\section{Segi Pembelajaran}

Keduanya dari perguruan tinggi mesir dan keduanya dari anggota perkumpulan bahasa Arab.

\section{Segi Pemahaman Pembaharuan}

(a). Keduanya sepakat menolak tanda i'rob far'iyah dan menolak fathah sebagai tanda I'rob.(b). Keduanya sepakat isim sesudah كان tidak ada isim kaana dan tidak ada khabar kaana karna keduanya tidak dari musnad dan musnad ilaih, adapun isim sesudah kaana 
dinamakan fail kaana dan adapun khabar kaana dinamakan hal kaana. (c). adapun dalam hukum isim sesudah kaada dan لا، لات saudaranya dan isim musyabihat dengan tanpa menggunakan

\section{Segi Qowaid Nahwu}

Keduanya sepakat dalam bab ظن dan saudaranya isim sesudah dzanna dinamakan maf'ul dan dan ashlinya mubtada khabar dan keduanya menolak terhadap dasar dan tidak adanya isim sesudah musnad dan musnad ilaih.

\section{Perbedaan Shauqi Dhaif dan Ibrahim Musthafa ${ }^{16}$}

\begin{tabular}{|c|c|c|}
\hline \multirow[b]{2}{*}{ Segi Analisis } & \multicolumn{2}{|c|}{ Perbedaan } \\
\hline & Shauqi Dhaif & Ibrahim Musthafa \\
\hline $\begin{array}{ll}\text { Segi } & \text { Dasar } \\
\text { Pembaharuan } & \end{array}$ & $\begin{array}{l}\text { Dalam kita Tajdid al- } \\
\text { Nahwu tampak jelas } \\
\text { dalam muqodimah } \\
\text { Dasar harakat } \\
\text { pembaharuannya } \\
\text { dalam pemahaman } \\
\text { ucapan kalimat dan } \\
\text { lembutnya lafadz } \\
\text { suara dan terjadi pada } \\
\text { setiap 'irob untuk } \\
\text { memperbagus dalam } \\
\text { ucapan. }\end{array}$ & $\begin{array}{lr}\text { Pada } & \text { dasarnya } \\
\text { terdapat pada kitab } \\
\text { Ihya al-Nahwu yang } \\
\text { paling penting dalam } \\
\text { keadaan } \\
\text { kalimat akhir } \\
\text { jumlah dalam } \\
\text { maknanya yang di } \\
\text { kumpulkan didalam } \\
\text { jumlah. }\end{array}$ \\
\hline Segi Qowaid nahwu & $\begin{array}{l}\text { Tidak menambah bab } \\
\text { dalam bab al-Tawabi' } \\
\text { seperti dalam al- } \\
\text { Khalib. } \\
\text { Membuang bab al- } \\
\text { Tanaazi dan al- } \\
\text { isytighal dalam bab al- } \\
\text { mansubat. }\end{array}$ & $\begin{array}{l}\text { Menambah bab } \\
\text { khabar dalam bab al- } \\
\text { tawabi' sehingga } \\
\text { terdapat lima bab } \\
\text { diantaranya na'at, } \\
\text { 'athaf, taukit, badal dan } \\
\text { khabar. } \\
\text { Membahas bab al- } \\
\text { Tanaazi dan al- } \\
\text { Isytighal dalam bab } \\
\text { al-takmilah al-Bahs. }\end{array}$ \\
\hline
\end{tabular}

${ }^{16}$ Kisno Umbar, Pembaharuan nahwu versi Ibrahim musthafa dan shauqi dhaif, (Malang : Skripsi UIN Maulana Malik Ibrahim, 2016). Hal. 135-139. 


\begin{tabular}{|c|c|c|}
\hline $\begin{array}{l}\text { Segi Pengetahuan } \\
\text { Nahwu }\end{array}$ & $\begin{array}{l}\text { Dalam kitabnya } \\
\text { pembaharuan nahwu } \\
\text { tidak terdapat batasan } \\
\text { dalam mengetahui } \\
\text { nahwu al-wadhih, dan } \\
\text { dari mengetahui } \\
\text { nahwu menurut } \\
\text { ulama terdahulu, } \\
\text { nahwu adalah ilmu } \\
\text { untuk mengetahui } \\
\text { berbagai hal pada } \\
\text { akhir kata arab dari } \\
\text { segi I'rob dan bina'. }\end{array}$ & $\begin{array}{l}\text { Nahwu merupakan } \\
\text { undang-undang } \\
\text { dalam menentukan } \\
\text { al-Kalam, dan } \\
\text { penjelasan pada } \\
\text { setiap kata yang } \\
\text { wajib dalam kata } \\
\text { jumlah, jumlah } \\
\text { beserta beberapa } \\
\text { jumlah, sehingga } \\
\text { memecah ibarat dan } \\
\text { memungkinkan } \\
\text { dalam penekanan } \\
\text { ma'nanya. }\end{array}$ \\
\hline
\end{tabular}

\section{Kesimpulan}

Pembaharuan nahwu menurut shauqi dhaif Dalam kita Tajdid alNahwu tampak jelas dalam muqodimah Dasar harakat pembaharuannya dalam pemahaman ucapan kalimat dan lembutnya lafadz suara dan terjadi pada setiap 'irob untuk memperbagus dalam ucapan. Sedangkan menurut Ibrahim Musthafa Pada dasarnya terdapat pada kitab Ihya alNahwu yang paling penting dalam keadaan akhir kalimat dalam jumlah dan maknanya yang di kumpulkan didalam jumlah.

Terdapat perbedaan antara Shauqi Dhaif dan Ibrahim Musthafa hal tersebut dikaitkan dengan segi dasar pembaharuan, segi Qowaid Nahwu dan segi pengetahuan nahwu, hal tersebut dapat dilihat bahwa Dalam kitabnya pembaharuan nahwu tidak terdapat batasan dalam mengetahui nahwu al-wadhih, dan dari mengetahui nahwu menurut ulama terdahulu, nahwu adalah ilmu untuk mengetahui berbagai hal pada akhir kata arab dari segi I'rob dan bina, sedangkan menurut Ibrahim Musthafa Nahwu merupakan undang-undang dalam menentukan al-Kalam, dan penjelasan pada setiap kata yang wajib dalam kata jumlah, jumlah beserta beberapa jumlah, sehingga memecah ibarat dan memungkinkan dalam penekanan ma'nanya. 


\section{Daftar Pustaka}

Abdullah. 2004. ad-Dars an-Nahwi fi al- qarn al-isyrin, Kairo: Maktabah Adab.

Ade Wahyu, A S. 2011. Perkembangan Ilmu Nahwu Kontemporer, Jakarta: Makalah UIN Syarif Hidayatullah.

Afandi,Zam Zam. 2015. Bias Tiologis dalam Linguistik Arab, Yogyakarta, Jurnal Adabiyat Vol. 7 No. 5.

Al Yasiri, Ali Muzhir. 2012. Al-Fikr al-Nahw 'inda al 'Arb Usulu wa Manahijuhu, Beirut: al Dar al-Arabiyyah Li al Maushu'at.

Al-Hasyimi, Al-Sayyid Ahmad, 2012, al-Qawaid al-Asasiyah Li al-Lughah al-Arabiyyah, Jakarta: Dinamika Berkah Utama.

Ardinal, Eva, 2013, Pemikiran Syauqi Dhaif Dan Upaya Pembaharuannya di Bidang Pengajaran Nahwu, Kerinci: Jurnal Islamika Vol. 13 No. 2.

Arifudin, 2013, Akademi Ilmu Tata Bahasa Arab di Andalusia: Kronologi dan Kontribusi. Surabaya, Jurnal Sastra Arab.

Chaqoqo, Sri Guno Najiib, 2015, Sejarah Nahwu, Salatiga: LP2M Press IAIN Salatiga Cet. 1.

Franciska, Toni, 2015. Konsep I'rob dalam Ilmu Nahwu "sebuah kajian epistemologis", Yogyakarta: Jurnal al-Mahara Vol. 1, No. 1.

Ghalayaini , Musthafa, 2011, Jami'ud Durus al 'Arabiyyah, Kairo: Darul Hadits.

Haniah, 2018, Analisis Kesalahan dalam Berbahasa Arab pada skripsi mahasiswa Jurusan Bahasa Arab dan Sastra Arab, Makassar: Arobi:Journal Of Arabic Studies Vol. 3 No. 1.

Hazuar, 2019, Konsep I'rab dalam Pandangan Ibrahim Mustafa dan Ibrahim Anis, Curup : Jurnal Arabiyatuna Vol. 3 No. 1.

Nazir, M. 1988. Metode Penelitian. Jakarta: Ghalia Indonesia.

Sugiyono. 2005. Memahami Penelitian Kualitatif. Bandung: CV. Alfabeta.

Umar, Kisno, 2016, Pembaharuan nahwu versi Ibrahim musthafa dan shauqi dhaif, Malang : Skripsi UIN Maulana Malik Ibrahim.

UmamawatI, Rena, 2016, Min Naqd Ibrahim Musthafa Fi Ba'd Al Masaail Al Nahwiyah Fi Kitabihi Ihya Al Nahwi, Surabaya: Tesis Universitas Islam Negeri Sunan Ampel. 